\title{
Cell Movement Process
}

National Cancer Institute

\section{Source}

National Cancer Institute. Cell Movement Process. NCI Thesaurus. Code C41517.

A Cell Movement Process consists of a change of position or place of a major cell

surface extension (such as cilia, axons, micorovilli, filopodia), or of a whole cell or a cell body from one site to another. 